卒後教青セミナー 5

荤頭領域癌に対する荤頭切除術の術後管理

\author{
東北大学第 1 外科 \\ 小山研 二
}

\title{
POSTOPERATIVE MANAGEMENT FOR PANCREATICODUODENECTOMY IN PERIAMPULLARY CARCINOMA
}

\section{Kenji KOYAMA}

Department of surgery, Tohoku university School of Medicine

察引用語：腪頭領域癌, 羘頭切除術, 高かロリー輸液

はじめに

脇頭領域癌の基本的根治手術は橧頭十二指腸切除術 であるが，これは，かつては極めて困難な手術で術後 合併症も頻発し，その治療的意義を疑問視する意見さ えみられた. しかし, その後の閉塞性黄疸時の肝病態 の解明"1. 胆管ドレナージを先行される二期的手術の 一般化，高カロリー輸液の進歩など多くの分野の発展 によって本術式は確立され極めて安全な手術となりつ つある. るちろん，その根治性において少なからぬ問 題があるるのの, 術式の安全性, 切除郭清範用の合理 性からして膵頭領域癌の基本術式としてょいものと考 える. 本稿では本手術の術後管理上の諸問題を, 教室 のこれまでの成績にもとづいて概説する。

\section{I. 自験例の概要}

教室におけるこれまでの朠頭領域癌手術例は，脺頭 部癌155例, 下部胆管癌73例, 十二指腸乳頭部癌48例で ある。このうち, 根治的切除例はこの順序に34例 $(22 \%), 41$ 例 (56\%)，33例 (69\%) で，これらの 5 年 生存率はそれぞれ9.1\%，27.6\%，31.6\%であった。 た根治切除108例中99例は满頭十二指腸切除術で 9 例 が膡全摘術であった。これらの経験から術後管理法に ついてのべる.

\section{II. 膵頭切除後の代辢変動}

羘頭切除により, 䐙内, 外分泌に関するラ島および 䐙腺房細胞の減少が生じ，そのために腪機能の低下と それに関連する諸種の代謝变動の招来されることが推

获第 5 回卒後教育セミナー・・愺頚部領域癌 $<1984$ 年10月17日受理 >別刷請求先：小山 研二 T980 仙台市星凌町 1-1 東北大学医学部第 1 外 科
察される．捇頭切除後の管理にはこの代謝変動の質と 量をあらかじめ知ることが必要である。

1. 内分泌能の変化

㬐頭切除術後の内分泌機能，特に耐糖能の変化を経 静脈性糖負荷試験（IVGTT）から検討した結果は以下 のごとくである、すなわち，教室松野ら 2 によると術後 1 カ月の検索では上昇した血糖值の回復がやや遅れる 傾向があるが術前値と有意の差はなかった。 また，糖 消失率 $\mathrm{K}$ 値は, 術前値1.23土0.25であったものが術後 は0.85士0.13に低下した。これらのうち, 術前值が1.1 以上の症例とそれ以下の症例に分けて術後の変動をみ ると両者ともほぼ同値に低下した。すなわち，衍前の 耐糖能とは無関保に術後に残存脇機能を中心とする耐 糖能はおおむね一定になるとの成績であった。

術後長期経過例において $50 \mathrm{~g}$ 経口糖負荷試験を行っ た成績は表 1 のごとくである，上段の悪性疾患では糖 尿病バターンを示すものは全体の $10 \%$ 以下で， $60 \%$ が 境界型，30\%が正常であり，また長期生存例では糖尿 病パターンを示すものはほとんどない，それに対し，

表 1 䐉頭切除例遠隔時の糖負荷試験成績

(50g OGTT)

\begin{tabular}{|c|c|c|c|c|c|c|}
\hline \multirow{2}{*}{ 原 疾 患 } & \multirow{2}{*}{$\begin{array}{l}\text { OGTT } \\
\text { バターン }\end{array}$} & \multicolumn{4}{|c|}{ 術後経過年数 } & \multirow{2}{*}{ 計 } \\
\hline & & $\sim 1$ & $1 \sim 5$ & $5 \sim 10$ & $10 \sim$ & \\
\hline \multirow{3}{*}{$\begin{array}{c}\text { 膵頭領域癌 } \\
(33 \text { 例 })\end{array}$} & 糟尿病型 & 40 & 0 & 0 & 14 & 9 \\
\hline & 境界 型 & 40 & 62 & 67 & 57 & 59 \\
\hline & 正 常 & 20 & 38 & 33 & 29 & 32 \\
\hline \multirow{3}{*}{$\begin{array}{c}\text { 眼性疾患 } \\
\text { (15例) }\end{array}$} & 糖康病型 & 75 & 50 & 50 & & 60 \\
\hline & 境界型 & 25 & 33 & 25 & & 27 \\
\hline & 正常 & 0 & 17 & 25 & & 13 \\
\hline
\end{tabular}


慢性晖炎を主とする良性疾患では60\%が糖尿病パター ンで正常は $13 \%$ みである。これら長期経過例からみ ると耐糖能の著明に低下している症例にすでに術前か ら障害されており，経過期間の延長とともに悪化して いくものではない.したがって耐糖能異常の問題点は むしろ慢性萃炎など良性慢性疾患にあり, 荤頭領域癌 では少なくとも術後に重篤な問題にはなり難いるのと 思われる。

\section{2. 苹外分泌機能の変化}

膵頭切除後の荤外分泌機能の評価は直接に脞液を採 取して量, アミラーゼ, 重炭酸塩の排泄量を測定する 方法もあるが簡便なるのとして BT-PABA テストが ある。これは膵キモトリプシンによって特異的に分解 される合成ぺプタイド BT-PABAを経口投与しその 分解産物 PABA の尿中排泄率を算定する方法であ る.したがって，この成績は膵実質の外分泌機能と膵 液の腸管内への流出状況一䐺管の開存性一に依存する ものである.

この BT-PABA テストを術前および術後 2 カ月を 経て行った18例の成績では, 術前值78.8土11.6\%で あったものが, 術後63.9土13.4\%に低下した。すなわ ち, 䡋頭切除によって約 $20 \%$ 低下するとの結果であっ た2). また術後経時的に長期にわたって BT-PABA テ ストを行った成績では大部分の症例は術後 2 カ月以後 は一定値を維持し, 術後経過時間とともに低下するこ とはない, 一方, 術後経過中 PABA テスト值が $80 \%$ か ら55\%，80\%から35\%，70\%から30\%などと明らかに 低下した症例は，いずれも残苹および周囲リンパ節を 一塊とし，荤管の開存も明らかに認められない程の癌 腫の再発例であった. したがって BT-PABA テストを 指標とするかきりり猝頭切除後はその組織欠損量に相当 する外分泌機能脱落はあるすのの経時的にそれが増悪 することはない.そして進行性の BT-PABA テスト值 の低下がある場合は癌腫の再発を示唆するものと考壳 られる。

消化吸収能む腪外分泌機能の指標であり，これを翼 便中の脂肪量から検討した教室能登らふの成績は以下 のごとくである. 膵頭切除例の遠隔検査時に消化酵素 剤を投与しない状態で霬便中脂肪量を測定したとこ ろ，17例中12例に脂肪排泄の増加を認めたが，1日10 $\mathrm{g}$ を越える大量の排泄例は 4 例のみであったという。

\section{3. 体重の変動}

術後の栄養, 消化吸収状態の総合的な指標である体 重の変動をみると術後 5 年以上の経過例はいずれる退
因 1 術後経過年数と䐙線維比率の増加

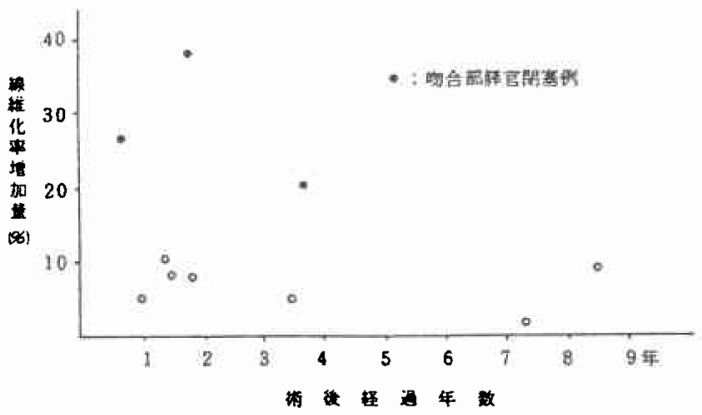

院時より増加している。また，早期に体重减少のみら れる症例の多くは癌の再発例であった2).

4. 術後残存膵の病態

腪頭領域癌に対する荤頭切除後長期間を経て死亡し た10例に対して剖検を行い，特に残存脞の検討を行っ た。教室松野ら 2)によると，手術から剖検までの期間 は, 8 力月から 8 年 6 カ月にわたるが, その荤線維化 率を手術時と剖検時で比較すると増加する傾向はある が経過期間とは相関せず，むしろ荤管空腸吻合部の開 存性に依存するすのと思われる。図 1 は手術から剖検 までの期間と，その間の線維比率の増加量を示すが, 脞管閉塞例に著しい増加がみられ，膵管の開存が保た れれば，術後す長期にわたって腪実質は温存されるこ とを示唆している。

次に，膵頭切除術残存膵からの膵液分泌の量的，質 的変化は以下のごとくである.手術時残存朠管に チューブを㨀入し，腸孺の形式で体外に誘導した朠管 ドレナージからの萍液量は, 術後次第に増加して第 6 病日ごろ一定値 (平均 $184 \mathrm{ml} /$ 日) となる。重炭酸塩排 出量, アミラーゼ排出量も術後次第に増加し, 前者は 1 週目，後者は10日目ごろに一定値になるがその平均 値は，各 $8.9 \mathrm{mEq} /$ 日，2,805U/日であった。

以上のべたごとく荤頭切除術の膵内，外分泌の機能 障害は比較的軽度で, 長期間経過して子はほ十定に保 たれる。したがって手術が円滑に行われ術直後に手術 に関連した合併症が生じないかぎり，術後管理上の重 大な問題はないと考えてよい. 脺頭切除の術後管理上 重要なことはこの, 術直後の合併症の予防と発生時の 対策および, 遠隔時の荤機能低下が多くの場合癌腫の 再発による膵管閉塞に由来することを理解しているこ とであるう。

\section{III. 亦頭切除術の合併症対策}

良性疾患を含めた膵頭切除術自騟130例の術後合併 
症は, 縫合不全 17 例 (うち直接死亡 4 例), 肝障害11例, 消化管出血 6 例，心肺合併症 5 例 ( 5 ち直接死亡 4 例), その他 4 例などである。このうち, 縫合不全は手術操 作に直接関連し重篤な結果になりやすい，教室例の縫 合不全の内訳は，苹管空腸吻合部が 12 例で最も多く， 他の 5 例は胆管空腸吻合部 3 例，結腸合併切除例にお ける回腸結腸吻合部などであった。一方，教室では， 1973年以前には腪頭切除後の再建様式に扣いて满管打 よび莝管のドレナージを行っていなかったが1974年以 後に胆管には Tチューブ, 腪管にはシリコンチューブ を挿入していずれも外瘦としている，縫合不全の頻度 と重篤度はこのドレナージの有無と関係し1973年以前 には縫合不全14例(うち 4 例死亡)，1974年以後には縫 合不全 3 例（死亡例なし）で，その発生率は各 $22 \%$, $5 \%$ と明らかに後者が低率，軽度であった ち, 膵頭切除術後の合併症は, 胆管, 腷管のドレナー ジとそれに加えて吻合部附近の腹腔内の適切なドレ ナージによって的確に予防され，仮に生じても重篤な 状態にならずに治癒するものと思われる。

一方，これらの術式の工夫とともに，最近進歩が著 しい各種栄養法による適切な術前, 術後管理も合併症 の予防，治療に不可欠の要素である．以下高カロリー 輸液を中心に特殊な栄養法の意義と問題点について述 ベたい.

\section{IV. 膵頭切除術後の栄養管理}

1. 高カロリー輸夜

教室では, 高カロリ一輸液と荤機能の関連性を, 脞 頭切除後荤管ト゚レナージを行った症例について検討報 告)しているがその概要は以下のごとくである。高カ ロリ一輸液施行 11 例の内訳は, 膵頭部癌 4 例, 荤内胆 管癌 4 例などで対照は脞内胆管癌 4 例など 5 例であ る. また，投与カロリーは1,620 2,800Cal, 平均 2,000 Cal (対照群780 1,200Cal, 平均930Cal), 糖投与量は, 高カロリ一輸液群は250 $565 \mathrm{~g} /$ 平均 $402 \mathrm{~g} /$ 日，（対照群 $75 \sim 250 \mathrm{~g} /$ 日, 平均 $145 \mathrm{~g} /$ 日), 高カロリ一輸液期間は 13 28日，平均20日間であった。この条件下での腪液 量は対照群が術後 $5 \sim 6$ 日で回復増加し以後一定値に なるのに対し，高カロリー輸液群では 8 10日後に一 定値になる.ただし両者間の膵液絶対量には大差なく， 前者が184.5, 後者が193.5ml/日であった。

アミラーゼ排出量も高かロリ一輸液群の回復が達く, さらにその絶対量も明らかに低值で，対照群が2,805 U/日であるのに対し1,371U/日であった，重炭酸塩排 出量は両群の間に大差はみられなかった。これらの成
図 2 䐙頭切除術後血清蛋白量と TPN

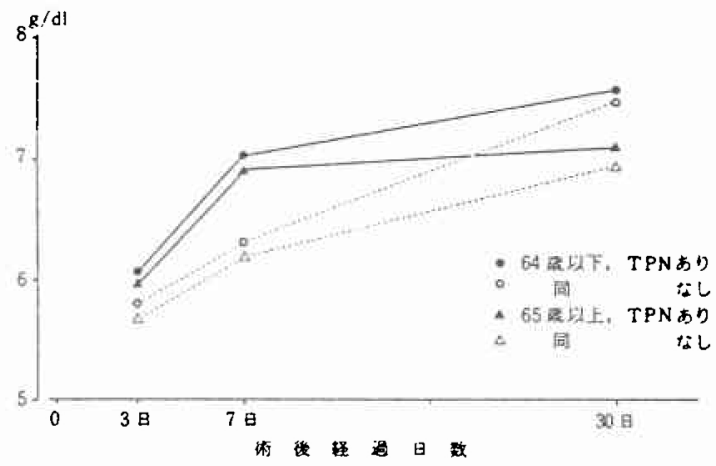

績は，高カロリ一輸液はその栄養効果を別にしても， 術後早期の腪外分泌を抑制し，䐙空腸吻合部の安静が 得られて手術の安全性を高める意義がある。

次に高カロリ一輸液栄養効果に術後血清蛋白量の変 動によって示される。教室武田ら 清蛋白量に対する高カロリ一輸液の意義を，特に高龄 との関与に打いて検討している，図 2 は膵頭妡除例を 65 藏未満と以上に二分し, さらに術後約 2 週間高力口 リ一輸液施行例について術後経時的に血清蛋白量を測 定した結果である。年齢層にかかわりなく術後 3 日目 血清蛋白は減少が著しいが第 7 病日で増加傾向を示 し，特に高カロリ一輸液群は良好に回復する。しかし， 高かロリー輸液を中止し経口栄養撕取している 1 カ月 後の值は高カロリー輸液を行った群も行わなかった群 も注注同等で，65歳以上の老龄者が明らかに低值を示 した。これは術後の高カロリー輸液が栄養状態の維持 改善に有意義であること，経口栄養掑取状態の良好な 壮年者では 2 週間前後の高カロリ一輸夜で十分である が，老齢者や経口摄取が十分でない症例では長期間持 続することが望ましいことを示している。

カロリー源としてはグルコースを主体とし脂肪はそ の大量投与が膵外分泌を刺激するとの報告もあること から術後早期には積極的に用いない方がよい。

2. 経腸成分栄養法（Elemental diet）

最近, 種々の特徵ある成分栄養剤が開発されており， 教室でも膵頭切除術の際に空腸瘦を作成して括き，術 後 ED-ACを用いた経験がある。その成績では，膵外分 泌対しては高カロリ一輸夜之同等な抑制効果があ り，かつ血清蛋白值からみても有効であった ${ }^{5)}$ 。しか し，この経腸的成分栄養法では，しばしば下莉がみら れ, , この際には所定の濃度よりも稀釈して用いたり, 可及的低速にして長時間かけて投与するなど症例に応 


\section{じた工夫が必要である.}

\section{3. 膵頭切除後のインスリン投与}

脇頭切除後の内分泌機能には先にのべたごとく著し い障害はなく、インスリンの投与を必要としない場合 が多い, しかし, 高かロリ一輸液や成分栄養法を行う 場合は考慮する必要がある。術前の耐糖能と高力口 リー輸液時のインスリン投与量 (必要量) との関係は 術前 GTT 正常例です 8 例中 3 例に15 32単位/日の インスリンを必要とした。境界型症例や糖尿病型症例 の必要量も同程度で, 術前の耐糖能の程度とインスリ ン量とは相関しなかった. したがって朠頭切除後の高 カロリー輸夜時のインスリン量は症例ごとに定めるこ とを原則とする。

経腸成分栄養法を行う際はインスリンを必要としな い場合が多いが，前述のごとく下㢉などの吸収条件の 差のために一律にインスリンを投与することが出来な い場合もあるので注意を要する。

$$
\text { おわりに }
$$

膵頭領域癌に対する基本的手術としての膵頭十二指 腸切除術の術後管理についてのべた. 苏頭切除術後の 代謝変動は膵内, 外分泌機能とも多少の障害はあるが, 生体が十分代償し得る程度のもので特殊な治療を要し ないのが通常である.しかし，この前提として胆管拉
よび脇管のドレナージを中心とする適切な手術操作を 必要とすることはいらまですない。

術後経過をより安全, 安定化するために高カロリー 輸液が有意義であり, 特に合併症のみられる場合や老 齢者には必須の治療手段である.この場合は症例に応 じたインスリン投与が必要である。

\section{文 献}

1) Koyama $K$, Takagi $Y$, Sato $T$ et al: Experimental and clinical studies on the effect of biliary drainage in obstructive jaundice. Am J Surg $142: 293-299,1981$

2）松野正紀, 武田和憲, 小針雅男注か：Child 変法再 建による羘頭十二指腸切除術一手術成續之術後の 病態を中心に一. 日消外会誌 $16: 2106-2111$, 1983

3）能登 訟, 斉藤洋一, 松野正紀ほか：苹頭切除後の 病態について。 日消外会誌 $10: 115-121,1977$

4）大和田康夫, 松野正紀, 本田毅彦ほか：膵頭十二指 腸切除術後の膵機能に及ぼす経中心静脈高力口 リー輸液の影響について。術後代謝研会誌 11 ： 471-474, 1979

5）武田和憲，松野正紀，宮下英士ほか：術後の栄養管 理一膵広汎切除後一. 老年医学 $22: 217-222$, 1984 